\title{
POTENSI INFUSA DAUN NANGKA SEBAGAI OBAT KUMUR HERBAL
}

\section{(THE POTENCY OF JACKFRUIT LEAF INFUSION AS A HERBAL MOUTHWASH)}

\author{
Christ Alfianus Tosubu, Nunung Sulistyani, dan Nur Khikmah \\ Akademi Analis Kesehatan Manggala Yogyakarta \\ Jl. Bratajaya No. 25 Banguntapan, Bantul, Daerah Istimewa Yogyakarta, Indoneisa - 55198 \\ email: nunungsulistyani@yahoo.co.id
}

\begin{abstract}
Abstrak
Penelitian ini dilakukan untuk mengkaji potensi daun nangka (Artocarpus heterophyllus) sebagai obat kumur herbal dengan melihat jumlah pertumbuhan koloni bakteri rongga mulut sebelum dan sesudah berkumur dengan infusa daun nangka. Daun nangka berwarna hijau muda yang diperoleh dari Babadan, Banguntapan, Bantul dibuat simplisia. Penentuan potensi dilakukan dengan menentukan perbedaan jumlah pertumbuhan koloni bakteri rongga mulut sebelum dan sesudah berkumur dengan infusa daun nangka. Uji potensi infusa daun nangka sebagai obat kumur dilakukan dengan menghitung perbedaan jumlah koloni bakteri rongga yang diperoleh dengan melakukan swab pada pangkal lidah sebelum dan sesudah berkumur. Perhitungan koloni bakteri dilakukan menggunakan metode hitung cawan (total plate count) pada media plate count agar (PCA). Hasil penelitian menunjukkan rata-rata jumlah koloni bakteri sebelum dan sesudah berkumur dengan infusa daun nangka yaitu 1,78 x $107 \mathrm{CFU} /$ $\mathrm{mL}$ dan 7,71 x $106 \mathrm{CFU} / \mathrm{mL}$. Perlakuan pemberian obat kumur infusa daun nangka secara signifikan mampu menurunkan jumlah koloni bakteri rongga mulut. Infusa daun nangka berpotensi sebagai alternatif obat kumur herbal.
\end{abstract}

Kata kunci: daun nangka, infusa, antibakteri, obat kumur herbal

\begin{abstract}
This study was conducted to examine the potential of jackfruit (Artocarpus heterophyllus) leaves as a herbal mouthwash by identifying the growth of bacterial colonies in the oral cavity before and after gargling with jackfruit leaf infusion. The light green jackfruit leaves obtained from Babadan, Banguntapan, Bantul were made simplicia. The determination of potency was done by determining the difference in the number of bacterial colony growth in the oral cavity before and after gargling with jackfruit leaf infusion. The potential test of jackfruit leaf infusion as a mouthwash was carried out by calculating the difference in the number of cavity bacterial colonies obtained by swab at the base of the tongue before and after gargling. Bacterial colonies were counted using the total plate count method on plate count agar (PCA) media. The results showed that the average number of bacterial colonies before and after rinsing with jackfruit leaf infusion was $1.78 \times 107 \mathrm{CFU} / \mathrm{mL}$ and $7.71 \times 106 \mathrm{CFU} / \mathrm{mL}$. The treatment of giving jackfruit leaf infusion mouthwash was significantly able to reduce the number of bacterial colonies in the oral cavity. Jackfruit leaf infusion has the potential as an alternative to herbal mouthwash.
\end{abstract}

Keywords: jackfruit leaf, infusion, antibacterial, herbal mouthwash 


\section{PENDAHULUAN}

Obat kumur banyak digunakan oleh masyarakat sebagai salah satu cara untuk menjaga kesehatan gigi dan mulut. Ganggu-an kesehatan gigi dan mulut antara lain karies gigi, periodontal, dan kanker. Hasil riset kesehatan dasar pada tahun 2018 menunjukkan bahwa masalah kesehatan gigi di Indonesia meliputi gigi rusak/berlubang/sakit menempati proporsi terbesar (45,3\%). Masalah kesehatan mulut mayoritas adalah gusi bengkak dan/atau keluar bisul abses (14\%) (Kemenkes RI, 2019).

Gangguan kesehatan gigi dan mulut yang terjadi pada masyarakat dapat menyebabkan hilangnya tingkat kepercayaan diri dan menurunkan produktivitas kerja. Kemenkes RI (2019) menyatakan salah satu faktor resiko gangguan kesehatan gigi dan mulut yaitu kurangnya menjaga kesehatan gigi dan mulut. Perilaku yang buruk dalam menjaga kesehatan gigi dan mulut dapat meningkatkan perkembangan bakteri dalam mulut. Bakteribakteri rongga mulut yang berdampak secara langsung ataupun tidak langsung pada kesehatan rongga mulut antara lain Streptococcus mutans, Streptococcus spp., Lactobacillus spp., Staphylococcus aureus, dan Enterobacter (Parahitiyawa, et al. (2010).

Obat kumur dapat digunakan untuk mengurangi pertumbuhan bakteri dalam mulut. (Sinaredi et al., 2014; Shin \& Nam, 2018). Adanya senyawa antiseptik dan antiplak pada obat kumur dapat mencegah terjadinya plak, karies gigi, gingivitis, dan bau mulut (Anyanwu et al., 2011).

Obat kumur non herbal yang banyak beredar di pasaran banyak mengandung alkohol. Adanya kandungan alkohol pada obat kumur dapat menimpulkan efek samping bagi penggunanya. Efek tersebut diantaranya adanya keluhan sensasi terbakar pada rongga mulut (Blanc \& Baruzzi, 2007; Lemos-Junior \& Villoria, 2008), menimbulkan nyeri pada mulut (Satpathy et al., 2013) dan menyebabkan perubahan warna gigi (Moreira et al., 2013).

Saat ini banyak diproduksi obat kumur berbahan dasar tanaman herbal. Penggunaan obat kumur herbal dapat mengurangi efek samping obat kumur nonherbal. Salah satu tanaman yang berpotensi digunakan sebagai obat kumur yaitu daun nangka (Artocarpus heterophyllus). Hal tersebut kemungkinan dikarenakan adanya senyawa aktifyang dapat menghambat pertumbuhan bakteri.

Yusriana dkk. (2014) menyatakan infusa daun nangka memiliki daya hambat terhadap bakteri Staphylococcus aureus. Sunaryono (2005) menjelaskan bahwa daun nangka memiliki manfaat bagi kesehatan karena mengandung antibakteri antara lain flavonoid, tanin, dan saponin.

Secara empiris masyarakat di desa Buanasari Parigi Sulawesi Tengah menggunakan rebusan daun nangka sebagai alternatif pengobatan, namun belum dilaku- 
kan pengujian secara ilmiah. Penelitian ini dilakukan untuk mengkaji potensi daun nangka sebagai obat kumur herbal dengan melihat jumlah pertumbuhan koloni bakteri rongga mulut sebelum dan sesudah berkumur dengan infusa daun nangka.

\section{METODE}

Daun nangka berwarna hijau muda yang diperoleh dari Babadan, Banguntapan, Bantul dibuat simplisia. Infusa daun nangka dibuat dengan mengekstraksi simplisia dengan air pada suhu $90^{\circ} \mathrm{C}$ selama 15 menit. Filtrat yang diperoleh merupakan infusa daun nangka dengan konsentrasi 100\%. Uji potensi infusa daun nangka sebagai obat kumur dilakukan dengan menghitung perbedaan jumlah koloni bakteri rongga mulut. Jumlah koloni bakteri dihitung menggunakan metode hitung cawan (total plate count) pada medium plate count agar (PCA) dan dinyatakan dalam satuan CFU/mL.

Responden yang digunakan pada penelitian ini sebanyak 14 responden yang dibagi dalam 2 kelompok, yaitu kelompok berkumur dengan infusa daun nangka dan kelompok berkumur dengan obat kumur komersial (bahan aktif metil salisilat 0,6 $\mathrm{mg} / \mathrm{mL}$ dan tiomol 0,64 mg/mL). Masingmasing kelompok responden berkumur sebanyak $20 \mathrm{~mL}$ selama 30 detik. Sebelum dilakukan uji potensi infusa daun nangka, responden diberikan penjelasan untuk tidak mengkonsumsi makanan dan minuman 1 jam sebelum berkumur.

Koloni bakteri rongga mulut diperoleh dengan melakukan swab pada pangkal lidah sebelum dan sesudah berkumur. Hasil swab pangkal lidah kemudian dimasukkan ke dalam tabung berisi $10 \mathrm{~mL} \mathrm{NaCl}$ fisiologis sebagai supensi uji. Selanjutnya, menyiapkan tabung pengenceran bertingkat yaitu $10^{1}, 10^{2}$, $10^{3}, 10^{4}, 10^{5}$ yang masing-masing berisi $9 \mathrm{~mL}$ $\mathrm{NaCl}$ fisiologis. Pada tabung pengenceran $10^{1}$ ditambahkan $1 \mathrm{~mL}$ (suspensi uji), kemudian dihomogenkan. Pada tabung pengenceran $10^{2}$ ditambahkan $1 \mathrm{~mL}$ larutan dari tabung pengenceran sebelumnya, kemudian dihomogenkan. Hal yang sama dilakukan sampai tabung pengenceran $10^{5}$. Inokulasi $0,1 \mathrm{~mL}$ dari tabung pengenceran $10^{5}$ pada medium PCA secara spread plate; diinkubasi pada suhu $37^{\circ} \mathrm{C}$ selama 24 jam. Pembacaan hasil dilakukan dengan mengamati dan menghitung jumlah koloni bakteri yang tumbuh pada medium PCA.

Data yang diperoleh dianalisis dengan Uji normalitas Saphiro-Wilk dilakukan dengan taraf signifikansi $>0,05$. Selanjutnya untuk membandingkan perbedaan jumlah koloni sebelum dan sesudah pada kelompok perlakukan menggunakan uji $T$ berpasangan dengan taraf signifikansi $<0,05$ dan uji T tidak berpasangan dengan taraf signifikansi $<0,05$ untuk membandingkan penurunan jumlah koloni antarkelompok perlakuan. 


\section{HASIL DAN PEMBAHASAN}

Perhitungan pertumbuhan koloni bakteri pada medium PCA dihitung dengan metode total plate count (TPC) pada pengenceran $10^{5}$. Pada masing-masing kelompok dilakukan perhitungan jumlah koloni sebelum dan sesudah berkumur. Hasil perhitungan rerata jumlah koloni bakteri pada masing-masing kelompok terlihat pada Tabel 1.

Tabel 1 menunjukkan bahwa terjadi penurunan jumlah koloni bakteri sebelum dan sesudah berkumur pada masing-masing kelompok. Uji $T$ berpasangan dilakukan untuk mengetahui pengaruh penurunan jumlah koloni bakteri pada masing-masing kelompok. Uji $T$ dilakukan setelah diketahui normalitas data menggunakan uji normalitas Saphiro-Wilk. Hasil uji normalitas data pada masing-masing kelompok sebelum dan sesudah berkumur terlihat pada Tabel 2. Tabel 2 menunjukkan bahwa data pada masing-masing kelompok perlakuan memiliki distribusi normal dengan nilai signifikansi $>0,05$. Selanjutnya, dilakukan uji $T$ berpasangan seperti terlihat pada Tabel 3 .

Tabel 3 menunjukkan adanya perbedaan bermakna pada masing-masing kelompok dengan nilai signifikansi $<0,05$. Berdasarkan uji statistik tersebut terdapat perbedaan penurunan jumlah koloni bakteri rongga mulut antara sebelum dan sesudah berkumur. Hal ini menunjukkan bahwa baik infusa daun nangka dan obat kumur komersial dapat menurunkan jumlah koloni bakteri rongga mulut.

Infusa daun nangka dalam menurunkan jumlah koloni bakteri rongga mulut menunjukkan adanya aktivitas antibakteri

Tabel 1

Rerata Jumlah Koloni Bakteri Rongga Mulut pada Kelompok Perlakuan Sebelum dan Sesudah Perlakuan Berkumur

\begin{tabular}{lcc}
\hline \multirow{2}{*}{ Kelompok Perlakuan } & \multicolumn{2}{c}{ Jumlah Koloni Bakteri $(\mathrm{CFU} / \mathrm{mL})$} \\
\cline { 2 - 3 } \multicolumn{1}{c}{ Sebelum Berkumur } & Sesudah Berkumur \\
\hline Infusa Daun Nangka & $1,78 \times 10^{7} \mathrm{CFU} / \mathrm{mL}$ & $7,71 \times 10^{6} \mathrm{CFU} / \mathrm{mL}$ \\
Obat Kumur Komersial & $1,19 \times 10^{7} \mathrm{CFU} / \mathrm{mL}$ & $5,58 \times 10^{6} \mathrm{CFU} / \mathrm{mL}$ \\
\hline
\end{tabular}

Tabel 2

Hasil Uji Normalitas Saphiro-Wilk pada Kelompok Perlakuan Sebelum dan Sesudah Perlakuan Berkumur

\begin{tabular}{lcc}
\hline & Kelompok Perlakuan & P value \\
\hline Infusa Daun Nangka & Jumlah Koloni Bakteri Sebelum Berkumur & 0,521 \\
& Jumlah Koloni Bakteri Sebelum Berkumur & 0,259 \\
Obat Kumur Komersial & Jumlah Koloni Bakteri Sebelum Berkumur & 0,551 \\
& Jumlah Koloni Bakteri Sebelum Berkumur & 0,449 \\
\hline
\end{tabular}


Potensi Infusa Daun Nangka (Tosubu, C. A. dkk.)

Tabel 3

Hasil Uji T Berpasangan antar Kelompok Sebelum dan Sesudah Berkumur

\begin{tabular}{llll}
\hline \multirow{2}{*}{ Kelompok Perlakuan } & \multicolumn{2}{c}{ Jumlah Koloni Bakteri } & \multirow{2}{*}{ P value } \\
\cline { 2 - 3 } & Sebelum Berkumur & Sesudah Berkumur & \\
\hline Infusa Daun Nangka & $1,78 \times 10^{7} \mathrm{CFU} / \mathrm{mL}$ & $7,71 \times 10^{6} \mathrm{CFU} / \mathrm{mL}$ & 0,000 \\
Obat Kumur Komersial & $1,19 \times 10^{7} \mathrm{CFU} / \mathrm{mL}$ & $5,58 \times 10^{6} \mathrm{CFU} / \mathrm{mL}$ & 0,001 \\
\hline
\end{tabular}

pada infusa daun nangka. Ekstrak etanol daun nangka mampu menghambat pertumbuhan Escherichia coli (Kusumawati dkk., 2017) dan Staphylococcus aureus (Mambang \& Rezi, 2018). Septama dan Panichayupakaranant (2018) menyatakan bahwa Artocarpus heterophyllus dapat menghambat pertumbuhan Streptococcus mutans.

Kemampuan aktivitas antibakteri infusa daun nangka diduga karena adanya kandungan senyawa antibakteri pada infusa daun nangka. Daun nangka memiliki senyawa antibakteri, seperti flavonoid, tanin, dan saponin (Tjay \& Rahardja, 2007).

Flavonoid mempunyai efek antivirus dan antibakteri dikarenakan gugus fenol yang dapat menghambat pertumbuhan bakteri dengan cara bereaksi dengan sel protein bakteri sehingga terjadi denaturasi atau kerusakan pada dinding sel bakteri yang menyebabkan lisis. Tanin mempunyai aktifitas antibakteri yang berhubungan dengan kemampuannya untuk mematikan sel mikroba dan enzim (Redha, 2010). Tanin juga mempunyai target pada polipeptida dinding sel sehingga pembentukan dinding sel bakteri menjadi kurang sempurna. Hal ini menyebabkan sel bakteri menjadi lisis kerena tekanan osmotik maupun fisik sehingga sel akan mati. Saponin sebagai antibakteri memiliki mekanisme dalam menurunkan tegangan permukaan sehingga mengakibatkan kebocoran sel dan sitoplasma keluar dari dalam sel (Sari \& Sari, 2011).

Untuk membandingkan penggunaan infusa daun nangka dan obat kumur komersial pada penurunan jumlah koloni bakteri rongga mulut dilakukan uji perbandingan antarkelompok berdasarkan rerata penurunan jumlah koloni bakteri pada masingmasing kelompok menggunakan uji $T$ tidak berpasangan. Sebelumnya dilakukan uji normalitas Saphiro-Wilk antarkelompok perlakuan (Tabel 4).

Tabel 4 menunjukkan bahwa data antarkelompok perlakuan memiliki distribusi normal dengan nilai signifikansi $>0,05$. Selanjutnya, dilakukan uji $T$ tidak berpasangan seperti terlihat pada Tabel 5 .

Tabel 5 menunjukkan adanya perbedaan bermakna antar kelompok perlakuan dengan nilai signifikansi $<0,05$ yang ditandai dengan adanya penurunan jumlah koloni bakteri 
Jurnal Penelitian Saintek, Vol. 26, Nomor 1, 2021

Tabel 4

Hasil Uji Normalitas Saphiro-Wilk Antarkelompok Perlakuan

\begin{tabular}{lcc}
\hline \multicolumn{1}{c}{ Kelompok Perlakuan } & Penurunan Jumlah Koloni & P value \\
\hline Infusa Daun Nangka & $101 \times 10^{4} \mathrm{CFU} / \mathrm{mL}$ & 0,151 \\
Obat Kumur Komersial & $64 \times 10^{4} \mathrm{CFU} / \mathrm{mL}$ & 0,9 \\
\hline
\end{tabular}

Tabel 5

Hasil Uji T Tidak Berpasangan Antarkelompok Perlakuan

\begin{tabular}{lcc}
\hline \multicolumn{1}{c}{ Kelompok Perlakuan } & $\begin{array}{c}\text { Rerata Penurunan Jumlah } \\
\text { Koloni }\end{array}$ & P value \\
\hline Infusa Daun Nangka & $101 \times 10^{4} \mathrm{CFU} / \mathrm{mL}$ & 0,025 \\
Obat Kumur Komersial & $64 \times 10^{4} \mathrm{CFU} / \mathrm{mL}$ & \\
\hline
\end{tabular}

rongga mulut lebih banyak pada penggunaan

infusa daun nangka dibandingkan dengan obat kumur komersial. Hal ini diduga konsentrasi kecil senyawa aktif antibakteri infusa daun nangka mampu menghambat pertumbuhan bakteri.

Obat kumur komersial yang digunakan dalam penelitian ini mengandung bahan aktif metil salisilat $0,6 \mathrm{mg} / \mathrm{mL}$ dan tiomol 0,64 $\mathrm{mg} / \mathrm{mL}$ sebagai antibakteri. Christian dkk. (2012) menunjukkan bahwa obat kumur yang mengandung metil salisilat tidak mampu menghambat pertumbuhan Staphylococcus dan Streptococcus asal rongga mulut yang ditandai dengan tidak terbentuknya zona hambat di sekitar kertas cakram. Senyawa aktif Artocarpin Artocarpus heterophyllus menunjukkan aktivitas kuat dalam menghambat pertumbuhan $S$. mutans pada konsentrasi hambat minimal sebesar 1,95 $\mu \mathrm{g} / \mathrm{mL}$ (Septama \& Panichayupakaranant, 2018).

\section{SIMPULAN}

Perlakuan pemberian obat kumur infusa daun nangka konsentrasi 100\% secara signifikan mampu menurunkan jumlah koloni bakteri rongga mulut. Infusa daun nangka berpotensi sebagai alternatif obat kumur herbal.

\section{DAFTAR PUSTAKA}

Anyanwu, O. C., Baugh, K. K., Bennett, S. B., Johnson, J. M., Madlock, R. L., Pollard, N. E., \& Chikwem, J. O. (2011). Comparison of the antibacterial effectiveness of alcohol-containing and non-alcohol-containing mouthwashes. $J$ Sci, 2, 7-12.

Blanc, S. A. L. D., \& Baruzzi, A. M. (2007). Mouthrinses containing alcohol and oral cancer: Revision of epidemiological studies. Brazilian Oral Research, 21(SPE), 16-22.

Christian, V.B., Indrawati, R., \& Sidarningsih. (2012). Perbedaan daya hambat obat kumur ekstrak teh hijau dan metil salisilat terhadap pertumbuhan bakteri rongga mulut (Thesis tidak diterbitkan). Universitas Airlangga, Surabaya.

Kementerian Kesehatan RI [Kemenkes RI]. (2019). Laporan nasional riset 
kesehatan dasar 2018. Kementerian Kesehatan RI.

Kementerian Kesehatan RI [Kemenkes RI]. (2019). InfoDatin: Kesehatan gigi nasional. Jakarta: Kementerian Kesehatan RI.

Kusumawati, E., Apriliana, A., \& Yulia, R. (2017). Kemampuan antibakteri ekstrak etanol daun nangka (Artocarpus heterophyllus) terhadap Eschericia coli. Jurnal Sains dan Kesehatan, 1(7), 327332.

Lemos-Júnior, C. A., \& Villoria, G. E. M. (2008). Reviewed evidence about the safety of the daily use of alcohol-based mouthrinses. Brazilian oral research, 22, 24-31.

Mambang, D. E. P., \& Rezi, J. (2018). Efektivitas antibakteri ekstrak etanol daun nangka (Artocarpus heterophyllus 1.) terhadap pertumbuhan bakteri Staphylococcus aureus. Jurnal Agroteknosains, 2(1), 179-187.

Moreira, A. D., Mattos, C. T., de Araújo, M. V. A., de Oliveira Ruellas, A. C., \& Sant'Anna, E. F. (2013). Chromatic analysis of teeth exposed to different mouthrinses. Journal of Dentistry, 41, e24-e27.

Parahitiyawa, N. B., Scully, C., Leung, W. K., Yam, W. C., Jin, L. J., \& Samaranayake, L. P. (2010). Exploring the oral bacterial flora: Current status and future directions. Oral Diseases, 16, 136-145. doi:10.1111/j.1601-0825.2009.01607.x

Redha, A. (2010). Flavonoid: Struktur, sifat antioksidatifdanperanannyadalam sistem biologis. Jurnal Belian, 9(2), 196-202. Diunduh dari http://repository.polnep. ac.id/xmlui/handle/123456789/144.

Sari, F. P., \& Sari, S. M. (2011). Ekstraksi zat aktif antimikroba dari tanaman yodium sebagai bahan baku alternatif antibiotik alami (Skripsi tidak diterbitkan). Fakultas Teknik, Universitas Diponegoro, Semarang.
Satpathy, A., Ravindra, S., Porwal, A., Das, A. C., Kumar, M., \& Mukhopadhyay, I. (2013). Effect of alcohol consumption status and alcohol concentration on oral pain induced by alcohol-containing mouthwash. Journal of Oral Science, 55(2), 99-105.

Septama, A. W., \& Panichayupakaranant, P. (2018). Artocarpin isolated from Artocarpus heterophyllus heartwoods alters membrane permeability of Streptococcus mutans. Journal of Applied Pharmaceutical Science, 8(06), 059-064. Diunduh dari http:// www.japsonline.com. DOI: 10.7324/ JAPS.2018.8608.

Shin A .R. \& Nam, S. H. (2018). The effects of various mouthwashes on the oral environment change for oral health care. Biomedical Research, 29(8), 1724-1729. DOI: 10.4066/ biomedicalresearch.29-18-534.

Sinaredi, B. R., Pradopo, S., \& Wibowo, T. B. (2014). Daya antibakteri obat kumur chlorhexidine, povidone iodine, fluoride suplementasi zinc terhadap, Streptococcus mutans dan Porphyromonas gingivalis (Antibacterial effect of mouth washes containing chlorhexidine, povidone iodine, fluoride plus zinc on Strep. Dental Journal (Majalah Kedokteran Gigi), 47(4), 211-214.

Sunaryono. (2005). Tumbuhan berguna Indonesia (Jilid II). Balai Litbang Kehutanan.

Tjay, T. H., \& Rahardja, K. (2007). Obat-obat penting khasiat, penggunaan dan efekefek sampingnya (Edisi Keenam). PT Eles Media Komputindo.

Yusriana, C. S., Budi, C. S., \& Dewi, T. (2014). Uji daya hambat infusa daun nangka (Artocarpus heterophyllus) terhadap pertumbuhan bakteri Staphylococcus aureus. Jurnal Permata Indonesia, $5(2), 1-7$. 